\title{
Legal Protection of Objections to Value Added Taxes Through the Tax Court
}

\author{
Muhammad Ghifari \\ Student at Doctoral Program of Law, Borobudur University, Jakarta Indonesia \\ Email: muhammadghifari05@gmail.com \\ Megawati Barthos \\ Borobudur University, Faculty of Law, Jakarta Indonesia \\ Azis Budianto \\ Borobudur University, Faculty of Law, Jakarta Indonesia
}

\begin{abstract}
The current taxation system is used to accommodate community activities that have not reached the target of development needs, among others, to increase state revenue, encourage exports, and equalize tax imposition. Keeping in mind the national taxation system, Law Number 42 of 2009 concerning Value Added Tax and Sales Tax on Luxury Goods or the VAT Law, is the legal basis that Value Added Tax and Sales Tax on Luxury Goods are two types of taxes that are regulated as one unit. as a tax on domestic consumption.

According to Law Number 42 of 2009 concerning the Third Amendment to Law Number 8 of 1983 concerning Value Added Tax on Goods and Services and Sales Tax on Luxury Goods, Value Added Tax is a tax on consumption of goods and services in the customs area which is subject to multilevel in every production and distribution line. Value added tax is a tax imposed on any added value of goods or services in circulation from producers to consumers.

In order to fulfill the obligation to pay the Value Added tax of the taxpayer determined by the tax directorate, this requires careful attention, especially if the value is large. If it turns out that the taxpayer has objections to the amount of tax imposition that is considered too large, then the taxpayer can take legal action through the Tax Directorate, then if there is still an objection, an appeal can be made through a tax court institution known as making an appeal in the tax court. Then if the taxpayers still object to them, they can carry out a reconsideration effort to the Supreme Court.
\end{abstract}

Keywords: Legal Protection, Taxpayers, Tax Court

DOI: $10.7176 /$ JLPG/108-09

Publication date: April $30^{\text {th }} 2021$

\section{Introduction}

National development, which has been and will continue to be implemented in order to create a just and prosperous society based on Pancasila and the 1945 Constitution, has implications for better economic and social life conditions for all Indonesian people, and raises the spirit of modernizing all areas of community life. To achieve this national development goal, a large amount of investment is required, the implementation of which must be based on one's own capacity.

The current taxation system is used to accommodate community activities that have not reached the target of development needs, among others, to increase state revenue, encourage exports, and equalize tax imposition. Keeping in mind the national taxation system, Law Number 42 of 2009 concerning Value Added Tax and Sales Tax on Luxury Goods or the VAT Law, is the legal basis that Value Added Tax and Sales Tax on Luxury Goods are two types of taxes that are regulated as one unit. as a tax on domestic consumption.

Sales Tax on Luxury Goods is collected once at the source, namely at the factory level, or at the time of import. Meanwhile, Value Added Tax can be collected several times at various company chain links. Even though they are collected several times, but because they are only imposed on the added value that occurs at each delivery of goods or services on the next line of the company, the tax burden is ultimately not heavier. Value added itself arises from the use of production factors in each company line in preparing, producing, distributing and trading goods or providing services to consumers. All costs of obtaining and maintaining profit, including capital interest, land rent, wages and entrepreneur's profit, are value added elements that form the basis for the imposition of Value Added Tax.

The rates that apply to the Delivery of Taxable Goods and Services are made simpler by applying a uniform rate, that is, one tariff for all types of Taxable Goods. Thus, its implementation becomes easier and does not require a list of classifications of goods with different rates. On luxury goods, apart from being subject to Value Added Tax, Sales Tax is also imposed as a concrete effort to uphold justice in tax imposition which is also 
an effort to reduce unproductive high consumption patterns in society. On the other hand, all goods which are unprocessed agricultural, plantation, forestry, fishery, livestock and other agrarian products are not subject to tax imposition.

Tax Invoice is a characteristic of Value Added Tax, because a tax invoice is evidence of collection which for Entrepreneurs that is collected can be calculated (credited) with the amount of tax owed. The special policy regarding creditable tax is imposed on entrepreneurs who in addition to handing over the goods to the taxable entrepreneur also hand over the goods to other people or entities who are not confirmed as taxable entrepreneurs, as well as for entrepreneurs who are taxed with the guidelines for calculating Input Tax on the delivery of goods.

Thus the multiplier effect of tax collection can be eliminated because the entrepreneur is only required to pay the difference between the tax that must be collected and the amount of tax he has paid. The multiplier effect only occurs in Sales Tax on Luxury Goods and this is done consciously to uphold the principle of fairness in tax imposition. ${ }^{1}$

However, in order to realize the principle of justice, it is possible to calculate the imposition of tax payments on the State as a taxpayer to object to the amount charged, so that the taxpayer has the right to sue legally and non-legally.

In the framework of procedural understanding which is regulated by the provisions regarding implementation procedures such as examination, tax assessment, additional tax provisions, administrative and criminal sanctions, as well as protection of the rights of individual taxpayers or legal entities or entrepreneurs, legal rights are given the opportunity to taxpayers. to file objections and appeals to the Tax Court, which is called the Tax Advisory Council as regulated in Law No. 28 of 2007 concerning General Provisions and Tax Procedures (KUP), as well as in this connection must be seen as an inseparable entity with Law Number 42 of 2009 concerning Value Added Tax and Sales Tax on Luxury Goods. This is because the Law on General Provisions and Tax Procedures contains provisions on procedures or procedures for implementing and sanctions taxation, as a complement to the material provisions contained in the Law on Value Added Tax on Goods and Services and Sales Tax on Luxury Goods. .

The mandate contained in the constitution of the Unitary State of the Republic of Indonesia, namely the amended 1945 Constitution, is that tax collection must be carried out in accordance with the Law. ${ }^{2}$ Thus, there is legal certainty in the application of tax law, with a tax system that uses self-assessment. Taxpayers are given the trust to carry out tax obligations without depending on the existence of a tax assessment letter. ${ }^{3}$

Another thing that is not less important, is that the imposition of the imposition of an incorrect amount of value on tax obligations related to VAT, it can be ascertained that there is an indication of arbitrary behavior that is unfair, which raises objections to objections that have implications for tax disputes. Tax disputes are basically disputes between individuals or private legal entities and state bureaucrats. State bureaucrats are equipped with compelling legal mandates and governing laws, while individuals or private legal entities are only in a practical objective condition in a weaker position to defend themselves against a taxation regulation, so what is important is to open channels of seeking justice for Public. ${ }^{4}$

Given the rapidly evolving tax provisions from time to time, this causes tax dispute resolution problems to be difficult for taxpayers to resolve. The tax dispute settlement effort carried out by the taxpayer through the tax court is an effort that is final in nature. This means that the Tax Court Decision is a final decision and has permanent legal provisions, as an effort of the law enforcement process.

Law enforcement according to Zudan Arif Fakrullah "In essence, it is an interaction between various human behaviors representing different interests within a framework of mutually agreed upon rules. Therefore, law enforcement cannot simply be considered as a process of implementing the law as legalists argue. However, the law enforcement process has a broader dimension than that opinion, because in law enforcement it will involve dimensions of human behavior. ${ }^{5}$

Basically, the activities carried out in the Tax Court are activities related to the efforts of taxpayers to seek justice and legal protection for a tax dispute, in connection with this, the laws and regulations and the officers in charge play an important role in the process. The formulation of the problem to be studied is: How is legal protection for taxpayers in the appeal process at the Tax Court.

\footnotetext{
${ }^{1}$ Dany Wirdarto, 2016, Sistem Peradilan Pajak di Indonesia, Jakarta, Pena Media, p. 81.

${ }^{2}$ Indonesia, Undang-Undang Dasar 1945Amandemen, Arcitle23 A

${ }^{3}$ Indonesia, Undang-Undang No 16 Tahun 2009 Tentang Tata Cara Perpajakan, arcitle 12

${ }^{4}$ Erna Widjajati, 2015, Hukum Pajak Bagi Negara Dan Masyarakat, Jakarta, RodaInti Media, $2015 . \quad$ p.

${ }^{5}$ Zudan Arif Fakrullah, 2011, Ilmu Lembaga Dan Pranata Hukum, Jakarta, Rajawali Pres, hal. 226.
} 31. 


\section{Research Methods}

The approach to the problem used in this paper is to use a normative juridical approach, namely literature law research and because this research is conducted by having library materials. In this study, a descriptiveanalytical type of research will be used with the reason that the results obtained from the literature study are then analyzed and discussed using a systematic discussion flow. Thus, the results of the analysis and discussion are then described to make it easier to draw some conclusions and submit suggestions

\section{Results And Discussion}

a. Self Assessment System

The tax reformation changed the tax collection system and mechanism from the Official Assessment System to the Self Assessment System. Self Assessment System is a tax collection system that provides authority, trust, and responsibility to taxpayers in determining the amount of tax payable annually in accordance with applicable laws and regulations.

Based on the implementation of the Self Assessment System, taxable entrepreneurs are expected to be able to carry out their tax obligations by registering themselves and being confirmed as taxable entrepreneurs. Law Number 42 of 2009 concerning the Third Amendment to Law Number 8 of 1983 concerning Value Added Tax on Goods and Services and Sales Tax on Luxury Goods, Article 15A paragraph 2 states that taxable entrepreneurs submit their SPT for the period of Value Added Tax at the latest. the following month after the end of the tax period. Based on the SPT reporting of the Value Added Tax period, a Tax Deposit Letter (SSP PPN) is generated, after the Taxable Entrepreneur deposits the tax payable to the designated payment place.

Self Assessment System is tax collection which gives authority, trust, and responsibility to taxpayers to calculate, calculate, pay and report the amount of tax to be paid by themselves. ${ }^{1}$

The self-assessment system causes taxpayers to be heavily burdened because all activities to fulfill tax obligations are carried out by the taxpayers themselves. Taxpayers must report all relevant information in the SPT, calculate the tax base, calculate the amount of tax owed, deposit the amount of tax owed. ${ }^{2}$

The Official Assessment System is a tax collection system that imposes the authority to determine the amount of tax owed to the tax authorities or tax officials as tax collectors. In the Official Assessment tax collection system, taxpayers are passive and the tax payable only exists after a tax assessment is issued by the tax authorities.

The characteristics of the Official Assessment tax system:

1) The amount of tax payable is calculated by the tax officer.

2) Taxpayers are passive in their tax calculations.

3) The tax payable exists after the tax officer calculates the payable tax and issues a tax assessment letter.

4) The government has full rights in determining the amount of tax that must be paid.

\section{b. Value Added Tax based on the Tax Law}

\section{1) Definition of Value Added Tax}

Value added tax (VAT) as the name implies is a tax imposed on the added value of a good or service in a transaction process. The definition of added value as referred to, namely "added value is the value generated by the producer which is added to raw materials or purchases including labor before selling new or processed products or services".

According to Law Number 42 of 2009 concerning the Third Amendment to Law Number 8 of 1983 concerning Value Added Tax on Goods and Services and Sales Tax on Luxury Goods, Value Added Tax is a tax on consumption of goods and services in the customs area which is subject to multilevel in every production and distribution line. Value added tax is a tax imposed on any added value of goods or services in circulation from producers to consumers.

2) Characteristics of Value Added Tax in Indonesia

Value Added Tax in Indonesia has characteristics that VAT does not have, including:

a) Indirect tax

b) Objective tax

c) Multi stage tax

d) Non-cumulative

e) Single fare

f) Credit Method / Invoice Method / Indirect Subtruction Method

\footnotetext{
${ }^{1}$ Melisa Sadiq, Srikandi Kumadji dan Achmad Husaini, 2015, Pengaruh Self Assessment System terhadap Penerimaan Pajak Pertambahan Nilai, Jakarta, Jurnal Perpajakan (JEJAK)| Vol. 7 No. 1 2015, p. 1.

${ }^{2}$ Abdurrachim, 2016. Pengaruh Self Assessment System Terhadap Penerimaan Pajak Pertambahan Nilai, Bandung, Alumni, p. 93.
} 
g) Tax on domestic consumption

h) Consumption Type Value Added Tax (VAT)

In the Value Added Tax in Indonesia, Input Tax on the purchase and maintenance of capital goods can be credited with the Output Tax collected on the delivery of Taxable Goods (BKP) and / or Taxable Services (JKP).

3) Tariff and Value Added Tax Imposition Base

a) Value Added Tax Imposition Rates

Value Added Tax Rate according to article 7 of Law no. 42 of 2009 are:

(1) Tariff $10 \%$ (ten percent).

The 10\% rate is imposed on each delivery of Taxable Goods within the customs area / import of Taxable Goods / delivery of Taxable Services within the customs area of the customs area which applies to the delivery of BKP and / or delivery of Taxable Services is a single rate, so that it is easy to implement. and does not require a list of classifications of goods or classifications of services with different rates.

(2) $0 \%$ (zero percent) export tariff.

This rate applies only to the export of Taxable Goods outside the customs area. The imposition of a Value Added Tax Rate of $0 \%$ does not mean exemption from the imposition of Value Added Tax, but the Input Tax that has been paid for exported goods can be credited.

(3) The aim is to encourage the growth of domestic product exports country.

Based on considerations of economic development and / or an increase in the need for funds for development. The government is given the authority to change the value added tax rate to be a minimum of $5 \%$ (five percent) and a maximum of $15 \%$ (fifteen percent) while still using the principle of the single rate. This tariff change is regulated by a Government Regulation.

\section{b) Basic Imposition of Value Added Tax}

According to Law no. 42 of 2009 , the basis for tax imposition is the total selling price, replacement, import value, export value, or other value used as the basis for calculating the payable tax.

(1) Selling Price is the value in the form of money, including all fees requested or should be requested by the seller due to the delivery of Taxable Goods, excluding the Value Added Tax collected under the Value Added Tax Law and the discount stated in the Tax Invoice.

(2) Reimbursement is value in the form of money, including all costs requested or should be requested by entrepreneurs due to the delivery of Taxable Services, export of Taxable Services, or export of Intangible Taxable Goods, but excluding the Value Added Tax collected under the Tax Law. Value Added and price discount stated in the Tax Invoice or value in the form of money paid or supposed to be paid by the Service Recipient due to the use of Taxable Services and / or by beneficiaries of Intangible Taxable Goods due to the use of Intangible Taxable Goods from outside the Customs Area in in the Customs Area.

(3) Import Value is the value in the form of money which is the basis for calculation Import duties are added with levies based on the provisions in the laws and regulations governing customs and excise for the import of Taxable Goods, excluding Value Added Tax and Sales Tax on Luxury Goods collected according to the Value Added Tax Law.

(4) Export Value is the value in money, including all costs requested or should be requested by exporters

\section{c. Legal Remedies for Objections of Taxpayers to the Director General of Taxes}

Regarding the case of objections to the imposition of tax payment value against taxpayers from the Tax Directorate, legal remedies in order to obtain justice. Procedurally, the actions taken by the Taxpayer, namely the submission of an objection letter by the Taxpayer submits an objection against the Director General of Taxes letter to the Tax Service Office where the Taxpayer is registered and / or where the Taxable Entrepreneur is confirmed directly or through their legal attorney as follows:

1) Submitted in writing in Indonesian;

2) Put forward an objection to the Director General of Taxes Letter of Appeal No. S-488 / PJ.51.1/ 2000 relates to If during a Tax Period, the Creditable Input Tax is greater than the Output Tax, the excess Input Tax cannot be recovered, but can be compensated at the next Tax Period which is considered contrary to the Law Value Added Tax Article 9 paragraph (4)

3) 1 (one) objection letter is submitted only for 1 (one) tax assessment, namely for Crediting Out Tax before the input tax is deposited,

4) Taxpayers are applying for Value Added Tax refunds at the end of the financial year;

5) Filed within a period of 3 (three) months from the date the tax assessment is sent or from the date the Taxpayer receives the letter from the Director General of Taxes; and

6) The objection letter is signed by the Taxpayer, and in the event that the objection letter is signed by a non-Taxpayer, the objection letter must be accompanied by a special power of attorney.

The Director General of Taxes also objected to the objection letter and rejected the written objection letter by the Taxpayer through a decree statement of rejection. Because the taxpayer still has not received the objection 
decision and still has an objection, the taxpayer takes the next legal action, namely by submitting an appeal to the tax court in accordance with Article 27 of the KUP Law.

\section{d. Legal Remedies for Appeal to the Tax Court}

Taxpayers object to the Director General of Taxes' objection assessment letter, so they can make an appeal based on Article 27 paragraph (1) of Law Number 16 of 2009 concerning Stipulation of Government Regulations in Lieu of Law Number 5 of 2008 concerning the Fourth Amendment to Law Number 6 of 1983 concerning General Provisions and Tax Procedures to Become Law, Taxpayers submit an appeal only to the tax court against the objection decree. The appeal filing process is carried out because the taxpayer has gone through an objection process.

If the appeal made by the Taxpayer turns out to be fruitless because the Tax Court rejects the Taxpayer's appeal with the Tax Court Decision, which has been deemed legally binding, then the Taxpayer can make legal reconsideration efforts to the Supreme Court, by attaching all files- files related to previous legal remedies.

\section{e. Legal Remedies for Reconsideration to the Supreme Court.}

Considering that the result of the decision of the Tax Court's Appeal by the Taxpayer is deemed not fulfilling a sense of justice and is considered to have permanent legal force, the Taxpayer, can take legal remedies for the Review of Tax Disputes to the Supreme Court. The taxpayer's legal action is a step that has a legal basis based on Article 93 paragraph 1 of Law Number 14 of 2002 concerning Income Tax to submit a review of the decision of the Tax Court to the Supreme Court. A taxpayer in a position as an Application for Reconsideration can only be submitted 1 (once) to the Supreme Court through the Tax Court. The application for reconsideration which ultimately cancels the decision of the tax court is a process of legal protection for taxpayers in an effort to seek justice.

Following up on the legal remedies for reconsideration at the Supreme Court by taxpayers with the status of a Reconsideration Request (PK Petitioner), the Supreme Court considers that the a quo review petition and its reasons have been carefully notified to the opposing party, submitted within a grace period and with cars determined by Law Number 14 of 1985 concerning the Supreme Court as amended by Law Number 5 of 2004 and the second amendment to Law Number 3 of 2009, in conjunction with Law Number 14 of 2002 concerning the Tax Court, then the request for review can formally be accepted.

The Taxpayer as a Reconsideration Applicant has submitted the following reasons for reconsideration:

1) There is New Written Evidence (Novum) which, if known at the trial stage at the Tax Court, may produce a different decision

2) There is new written evidence (novum).

3) Position of Previous Judgment Case

Article $13 \mathrm{KK}$ concerning PPN and PPnBM obligations, which number 6 point (v) states that in the event that the Input Tax (abbreviated as PM) is greater than the Output Tax (PK) for a tax period, the excess Input Tax (abbreviated as PM) is compensated with Tax. Output (PK) for the next tax period, except for the overpayment of PM due to export and / or delivery to a Value Added Tax collector, can be submitted for a refund at each Tax Period. Furthermore, point 6 point (vii) states that the PM for the transferred Taxable Goods and / or Taxable Services is in point (vi) (for Taxable Goods and / or Taxable Services that are directly related to the KK project obtained by shareholders which is part of expenditures before the company is established which is then transferred to the company can be credited by the company as long as it has not been credited by the shareholders. KK as an agreement between the Government of Indonesia and the taxpayer binds the Government and according to the postulate pacta sun servanda (must be obeyed) and / ex speciali derogate lex generali, then the provision number 6 point (vii) applies overriding Article 9, Paragraph (8) b, Value Added Tax Law. If the PM of Taxable Goods and / or Taxable Services obtained by the shareholders prior to the establishment of the Taxpayer which is then transferred as part of their participation can be credited by the Taxpayer, moreover those obtained by the taxpayer themselves must clearly be credited. Therefore, regardless of the provisions of Article 9 Paragraph (2) and 9 Paragraph (8) b of the Value Added Tax Law, in accordance with the provisions of Article 13 point 6 point (vii) PSC, all Input Tax (abbreviated as PM), on Subjected Goods. Taxes and / or taxable services obtained by taxpayers in 2008 and 2009 can be credited. Furthermore, on the creditable PM, based on the provisions of number 6 point (v), because it is not caused by export and / or delivery to the Value Added Tax Collector, the excess PM is compensated with Output Tax (PK) for the next tax period. Article 9 (10) of the Value Added Tax Law states that if at the end of the financial year (December) there is an excess of PM as referred to in paragraph (4), then a request for refund can be submitted for the excess PM. There are differences in the treatment of excess PM at the end of the financial year, if in a special regulation (KK) it can only be compensated for the next tax period, however in the general rules of the Value Added Tax Law, a refund request can be submitted. If the taxpayer chooses to return, the choice must be implemented without hindrance.

\section{f. Position of Supreme Court Reconsideration Decision Case}

In the Supreme Court Decision Number Supreme Court Decision which cancels the previous Tax Court Decision Number Decision, it shows that in a tax dispute between the Taxpayer and the Director of Taxes or the 
tax authorities due to uncertainty in the application of the law in this case the Law on Value Added Tax, Article 9 paragraph (2) states that Input Tax in a Tax Period is credited with Output Tax in the same Tax Period, here there is no prohibition or limitation for crediting input tax and output tax, so if the Director General of Taxes orders all mining companies holding work contracts not to credit income tax before the expenditure tax is paid, it violates the Value Added Tax Law and even adds a new norm to the Law.

1) The Disputing Parties

In the study of tax disputes based on the decision of the Tax Court Appeal and the Decision of the Supreme Court Tax Dispute PK, if we look at the specifications, according to the author, the parties to the dispute are the government as the fiscus and the people as the taxpayer or tax bearer. In this case, the Fiscus is positioned as the defendant / defendant or the party receiving the objection. Meanwhile, on the other hand, it is the people as taxpayers or tax bearers who file an appeal against the objection. The object of the dispute is a government decision in the tax sector aimed at the people as taxpayers who are deemed to be detrimental to the taxpayer concerned. The dispute was triggered by the existence of a state administrative decision in the tax sector which the taxpayer was questioned because he felt that he was aggrieved by the decision.

2) Legal Analysis of the Supreme Court Reconsideration Decision

a) Legal principles in AUPB that must be obeyed by the Appealee in every issue or giving legal treatment to. the public (including the Appellant Petitioner) is the principle of legal certainty, the principle of legal order and the principle of professionalism.

b) Different legal treatment for the same events and legal conditions is a form of violation of the AUPB that can harm the legal interests of other parties, including the Appellate Petitioner.

c) On all consideration of the facts of the evidence which are used as legal facts by the appellant;

Legal Considerations The Supreme Court is of the opinion that for the reasons for the reconsideration, the Petitioners' petition for reconsideration can be justified. Thus, the reasons for the petition of the Petitioner for Reconsideration are justified, because there is a decision of the Tax Court that is contrary to the provisions as stipulated in Article 91 letter e of Law Number 14 of 2002 concerning the Tax Court. Based on these considerations, according to the Supreme Court there is sufficient reason to grant the petition for reconsideration submitted by the Petitioner for Reconsideration.

And the Supreme Court will try the case again, with warnings as to be stated.

a) Amendment of the Supreme Court Decision, numbered, is an answer to the cancellation of the appeal rejection of the appeal Applicant at the previous Tax Court, as well as whether or not to grant the request for reconsideration from the Petitioner for Reconsideration.

b) To order the Respondent for Reconsideration to pay the court fee in the review hearing.

In the position of rejection of the Petitioner for Reconsideration, it can be concluded that the Taxpayer is treated unfairly by the decision of the Tax Court Appeal. Unfair treatment of taxpayers on the decision on the appeal of the tax tribunal which is considered to have permanent legal force, it is evident that the Supreme Court considers that after the verdict which has permanent legal force, the previous decision of the tax court is dismissed and it is notified to the applicant for reconsideration. Then by the Supreme Court, against the Taxpayer as an applicant for Reconsideration by the Petitioner for Reconsideration or through his attorney, the application for Reconsideration by the Taxpayer along with its evidence and legal arguments, was accepted by the Supreme Court, and the decision on the Tax Court's Appeal also stated the legal considerations of the Assembly. The Tax Court, at the level of the Tax Court Appeal, is declared invalid.

\section{Closing}

Based on this brief study, the author can conclude that in order to fulfill the Value Added tax payment obligations of taxpayers who are determined by the Tax Directorate officials, this requires careful attention, especially if the value is large. If it turns out that the taxpayer has objections to the amount of tax imposition that is considered too large, then the taxpayer can take legal action through the Tax Directorate, then if there is still an objection, an appeal can be made through a tax court institution known as making an appeal in the tax court. Then if the taxpayers still object to them, they can carry out a reconsideration effort to the Supreme Court.

As a suggestion from the author, the Director General of Taxes should in issuing a decision carefully consider the provisions of Law No. 28 of 2007 concerning General Provisions and Tax Procedures (KUP), as well as in this connection must be seen as an integral part that cannot be separated from Law Number 42 of 2009 concerning Value Added Tax and Sales Tax on Luxury Goods.

So that in determining the amount of tax imposed on taxpayers, it fulfills the principle of justice. This is because every law is a legal norm that must be enforced in order to provide legal certainty and justice. Therefore, if the law is not considered or not given careful attention, it will have an unfair impact on the taxpayer. For this reason, the Tax Court must consider the applicable Value Added Tax Law, so that in issuing a decision it is not detrimental to the taxpayer. 


\section{Bibliography}

Books

Abdurrachim, 2016, Pengaruh Self Assessment System Terhadap Penerimaan Pajak Pertambahan Nilai, Alumni, Bandung.

Dany Wirdarto,2016, Sistem Peradilan Pajak di Indonesia, Pena Media, Jakarta.

Erna Widjajati, 2015, Hukum Pajak Bagi Negara Dan Masyarakat, RodaInti Media, Jakarta.

Melisa Sadiq, Srikandi Kumadji dan Achmad Husaini, 2015, Pengaruh Self Assessment System terhadap Penerimaan Pajak Pertambahan Nilai, Jurnal Perpajakan (JEJAK)| Vol. 7 No. 1, Jakarta.

Satjipto Raharjo, 2005, Masalah Penegakan Hukum Suatu Tinjauan Sosiologis, Sinar Baru, Bandung.

Zudan Arif Fakrullah, 2011, Ilmu Lembaga Dan Pranata Hukum, Rajawali Pres, Jakarta.

\section{Laws and regulations}

Indonesia, Undang-Undang Dasar Negara Republik Indonesia Tahun 1945

--------, Undang-Undang No 16 Tahun 2009 Tentang Tata Cara Perpajakan

-------, Undang-Undang No. 28 Tahun 2007 tentang Ketentuan Umum dan Tata Cara Perpajakan (KUP)

--------, Undang-Undang Nomor 42 Tahun 2009 tentang Pajak Pertambahan Nilai dan Pajak Penjualan atas Barang Mewah 